\title{
Winston Mair to Speak at S.N.H.S. Annual Meeting
}

Winston Mair, Chief of the Canadian Wildlife Service, will be the gues speaker at the annual meeting of the S. N. H. S. to be held in the Saskat chewan Museum of Natural History, Regina, on October 18 and $19 . \mathrm{Mr}$ Mair will speak Saturday evening on "Conservation in Canada".

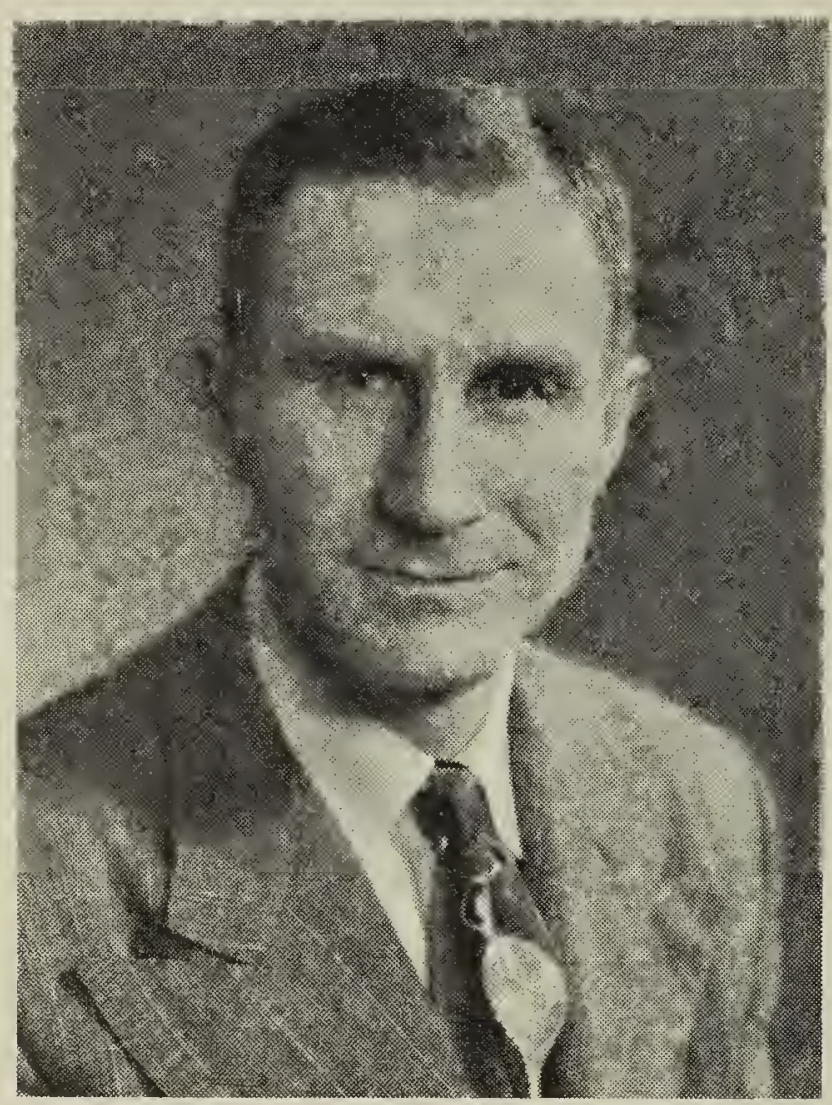

National Film Board Photo

Winston Mair was born and raised on a farm at North Battleford, and took an active part in the activities of the agricultural community there. When he returned from overseas service in 1946, he went to the University of British Columbia to take his M.A. degree in Zoology, with specialization in Wildlife Management. After working with the British Columbia Game Ccmmissicn as Supervisor of Predator Control, and then on the Defence Research Board at Fort Churchill for a short period, Mair was called to Ottawa in 1952 as the Chief cf the Wildlife Service.

Since Mr. Mair's appointment as Chief of the Wildlife Service, additional wildlife men have been added to the Service to carry out research programmes vital to the welfare of many species of wildlife. Biologists of the service, stationed throughout the various provinces of Canada, work closely with the United States Fish and Wildlife Service, provincial game personnel and Ducks Unlimited on waterfowl population studies and banding programmes.

A wildlife research project whic is being carried on again this year i Saskatchewan by the Service is des cribed on page 110 of the Blue Ja by J. Bernard Gollop, a Canadia Wildlife officer. Another example their work is the co-operative surve of barren ground caribou inaugurate through the efforts of the Servic working closely with Northwe Territories, Saskatchewan and Mar itoba Game Administrations as we as the Department of Indian Affair Agencies interested in wildlife re: ources have been drawn into a clos working unit by leadership provide by Mr. Mair since his appointme as Chief of the Service.

\section{PROGRAM}

Evening Session, Friday, Oct. 18 the Museum-executive meeting 8:00 p.m.; social get-to-gether which all members are invited, 9:30 p.m.

Morning and Afternoon Session Saturday, Oct. 19 at the Museum registration at 9:00 a.m.; businf and programme sessions at 9:30 a.s and 1:30 p.m.

Evening Session, Saturday, Oct. at the Museum-address by Winst Mair at 8:00 p.m.

\section{NOMINATIONS AND RESOLUTIONS}

Send suggestions for the nomin. ations and resolutions committee to the Corresponding Secretary Margaret Belcher, Regina College Regina before October 5, 1957 Write the secretary also for fur ther programme details.

\section{KODACHROMES}

A limited time will be availal for members' items. If you ha kodachromes, bring ten to show this time; if you have other items interest, bring them for display $d i$ ing the sessions. 